\title{
A Proposed Infographics-Based ESP Course for Enhancing Graduate Nursing Major Students' critical Reading Skills and Motivation
}

By

\author{
Rehab Hamadtoh Abul-Ghait Gohar
}

Lecturer of Curriculum \& Instruction: TEFL

Faculty of Education, Mansoura University

Contact.rehabh.gohar@gmail.com

\begin{abstract}
This research aimed at examining the effect of a proposed infographics-based ESP course on enhancing graduate nursing students' critical reading skills and their motivation towards reading. The sessions of the ESP course were designed following the pre-while-post reading phases. The course made use of genuine/authentic reading texts and infographics in addition to some tools such as Facebook, Piktochart and Padlet for helping students to interact, design and publish their infographics. Besides, multiple tasks for encouraging students' discussion, collaboration and critical thinking were provided. Participants included one hundred students enrolled in the second year of the specialized nursing diploma, Faculty of Nursing, Mansoura University. The quasiexperimental design was adopted in which the participants were assigned into two groups: a control group (studied through the regular English course) and an experimental group (studied through the ESP course based on infographics). Instruments used in the research were a critical reading skills questionnaire, a criteria checklist for infographics use and design, a critical reading skills test and a reading motivation scale. Results revealed that the experimental group students outperformed their counterparts of the control group in the target critical reading skills. Besides, the students' post motivation level of the experimental group was enhanced compared to their pre-level and to the control group's post motivation level as well. As a result, the ESP course based on using infographics proved its significant effect on enhancing the graduate nursing students' critical reading skills and motivation towards reading.
\end{abstract}

Key words: ESP, critical reading, motivation and infographics. 
A Proposed Infographics-Based ESP Course for Enhancing Graduate Nursing Major Students' critical Reading Skills and Motivation

\section{Introduction:}

English is the most dominant used language due to the globalization that supports interaction and communication among people from all over the world. Governments have implemented various aspiring instructive changes to profoundly integrate English into their educational curricula in order to qualify their learners with the linguistic skills needed everywhere in the world. The implementation of English in education and mainly on the university level has become an urgent necessity through designing English courses to meet the needs of the diversified students of different specializations (engineering, biology, nursing, and so on). This goal-directed approach is reached by the teaching of a special type of English commonly known as English for specific purposes, or simply (ESP).

The field of ESP addresses the communicative needs and practices of particular professional or occupational groups. It has developed rapidly in the past forty years to become a major branch in the teaching and research of the English language. The strength of ESP is based an eclectic theoretical foundation and a commitment to research-based language education which aims at revealing the limitations of social contexts on language use and how learners can gain control over these through the various means of mastering the different language skills (Hyland, 2007).

ESP emphasizes the importance of reading since it is an essential skill in many teaching and learning situations depending on the fact that ESP learners need to be able to read well, understand, learn about their specialization, gather information and thus achieve academic and professional success. For enhancing the development of the reading in general and critical reading in particular, infographics can be considered as a powerful source for engaging students in critical analysis via close reading. Davis and Quinn (2013) stated that infographics can support reading comprehension while strengthening critical thinking and synthesizing skills. Krauss (2012) also suggested using infographics as a tool for engaging and developing analysis and interpretation capabilities either when students interpret the graphics or when they create them.

This research explored the integration of infographics in ESP teaching in general and teaching reading skills in particular. It examined how infographics with the use of some web 2.0 tools like Facebook, Padlet and Piktochart offer opportunities for students to develop their critical thinking, reading skills and motivation. 


\section{Review of related literature:}

Since the 1960s, ESP has become one of the most active branches of Applied Linguistics in general, and of Teaching English as a Foreign Language (TEFL) in particular. It is a term that refers to teaching or studying English for a particular specialty (like law, medicine, business). In other words, there is a specific reason for which English is learned. Research on ELT reveals that ESP has emerged not from a structural theory of language but from a functional basis of learner needs. ESP is considered as a sub-branch of the general activity of teaching English. It is also described as 'a communicative EGP' (English for general purposes). Indeed, methodology has been generally neglected in ESP since the focus has been on 'what' ought to be taught (the content) rather than on 'how' it should be taught (Larouz \& Kerouad, 2016).

The purpose and how to reach it is what distinguishes ESP from EGP. ESP is mainly a training operation for equipping learners with a restricted language competence to help them cope with particular clearly-defined tasks. These tasks represent the certain purposes which the ESP course is intended to achieve; while the purpose of EGP is meant to develop a general capacity of language use in which syllabi are usually predetermined in advance of teaching. Unlike EGP, the starting point for curriculum development in an ESP context is an analysis of learners' needs rather than a linguistic analysis; thus, the teacher should consider his/her students' needs, unlike the EGP teacher who may have a set of 'cooked material' made available for him/her not only to implement in a language classroom but also to cover in a limited time-span. In this vein, it is claimed that EGP is a top-down approach whereas ESP may be regarded as a bottom-up approach in which the teacher starts from students' needs before considering other issues such as course design, methodology or evaluation (Popescu, 2010).

Bracaj (2014) indicated that EGP is basic language learning to be learnt before, but not during college; college English should be more advanced and specialized; it should match students' fields of study, especially in technological or medical universities where students are trained to perform on-the-job. Finally, compared with EGP, ESP is more effective in enhancing students' motivation because it is associated with their majors of study and is directed to their needs. It was also added that ESP is widely open to team teaching and it fits best with the communicative approach not with the traditional methods. 


\section{A Proposed Infographics-Based ESP Course for Enhancing Graduate Nursing}

\section{Major Students' critical Reading Skills and Motivation}

In spite of the previously mentioned above differences between ESP and EGP, they both use the same concepts and approaches. One such concept is authenticity since using authentic materials in language classes would serve learners needs and help them engage in the learning process. Besides, within ESP and EGP contexts, learners are required to use the same skills and strategies according to the target situation. Moreover, English language teaching in general and ESP in particular adopt the same process-based approaches (content, task and product-based approaches) in an attempt to help learners develop the skills related to language learning and also those related to their own discipline of study (Kirkgoz, 2007 and Larouz \& Kerouad, 2016).

Based on learners' motivation, position, and reasons of learning, Bracaj (2014) and Lamri (2016) illustrated that ESP might have two types: 1) English for Occupational Purposes (EOP) in which learners need to use English as a requirement for their work or profession. EOP learners are likely to be adults who aim at improving their job performance and who have a long-term goal to enhance their English communication skills of work and life. 2) English for Academic Purposes (EAP) is presented within higher educational institutions to learners requiring English in their studies. Accordingly, mastering study skills such as listening to lectures, taking notes, writing reports, summarizing lectures and reading textbooks will probably be a main demand of the student's English course.

Dudley and Johns (1998) illustrated that the features of ESP can be either absolute or variable. Absolute characteristics include that: ESP is defined to address learners' specific needs, it uses the methodology and activities of the target discipline, and it concentrates on the language (grammar, lexis, register), skills, discourse and genre suitable to these activities. On the other hand, variable ESP characteristics are: ESP may be directed to particular disciplines, it may use different methodology from that of general English in a particular teaching situation, and it is likely to be designed for advanced learners.

In this concern, Hutchison \& Waters (1987) and Lamri (2016) indicated that the absolute features are specific to ESP since the design of language activities is centered around learners' needs. Regarding the variable features, ESP courses can be designed for a specific group using particular teaching methodology; however, all learners' categories and disciplines can be concerned with ESP. Accordingly, ESP should be seen simply as an 'approach' to teaching since all decisions related to content 
and methodology are based on the learner's purpose for language learning.

Since ESP is regarded as a methodology for teaching English designed for specific disciplines based on learners' purpose of learning (Marenzi \& Kantz, 2013), an integrated approach for ESP course design was recommended by Nurpahmi (2016). Such an approach integrates teacher-centered learning, learner-centered leaning, skill-centered approach and learning-centered approach. The integrated approach starts with analyzing the needs of the learners which are central for the course design; this includes gathering information about the learners and identifying the target situation and context of learning ESP. After conducting the required needs analysis, the next steps are creating syllabus and developing the required materials. In this step, course designer integrates content material and functional language. Then comes the implementation and teaching the ESP course which must integrate student-centeredness and teacher guidance. The teacher is nor the only source of the material, but s/he plays a key role to facilitate learners' language learning. Evaluating students' progress is the final part in course design. Salazar (2017) recommended different evaluation tools for evaluating students such as language-learning logs, portfolios, role plays, audio and video recordings and final work projects.

Many studies were conducted in the field of ESP whether in Egypt or worldwide. For example, an Egyptian study, by Abdel-Ghany and AbdelLatif (2012) examined the English courses provided for tourism and hospitality undergraduates in Egypt and its adequacy as regarded by students and teachers. Analyzing interview data reflected that the provided English language courses have some shortcomings; and that the participants recommended reshaping them in a manner that could optimally help students be well-prepared for meeting their future workplace needs.

In addition, Ali (2015) assessed the motivations and attitudes of undergraduate Egyptian students in ESP classes. The findings indicated that students are intrinsically and extrinsically motivated and they have a deep interest toward ESP courses. However, there are multiple elements that might negatively affect the students' attitudes and motivations such as unrelated course materials, inappropriate course schedules, lack of educational technology into classroom teaching, poor teaching methods or the learning environment. 
A Proposed Infographics-Based ESP Course for Enhancing Graduate Nursing Major Students' critical Reading Skills and Motivation

Popa (2013) also assessed the issue of English for medical professionals (EMP) in Romania where research on EMP is almost rare. It was revealed that most if not all of today's Romanian medical universities and faculties provide their students with at least a one year course to meet students' varied needs and goals concerning the necessary language skills for coping with the linguistic requirements of their specialization. The course also enables the students to use English in a proper and fluent manner in their professional environment.

Another research was conducted in Ukraine to assess students' attitudes towards studying ESP in the university and to determine the English language skills that are important for them. Participants were 439 second year students from different faculties. Analyzing the collected data indicated that students had a positive attitude towards ESP instruction. It was recommended that in order for addressing learners' specific needs, the content of the ESP course should focus on both general (academic) and specialized English elements. The course should start as General English for improving learners' listening comprehension, reading, writing, and speaking skills. Then, the focus can shift towards Discipline Specific English for Academic Purposes to enhance discourse, vocabulary, and register specific to the specialization of study (Belyaeva, 2015).

Vanicheva, Kah and Ponidelkoa (2015) concluded that focusing on improving the language of ESP students led to training their memory and enhancing their ability to voice ideas, processes and concepts through applying learnt vocabulary for a specific purpose. Besides, Bouklikha (2016) conducted an experimental case study of second year Master's Students to examine the use of web-based materials into a content-based ESP course. Data analysis revealed that Master's students needed to develop particular reading sub-skills and strategies to reinforce their linguistic background in English and to raise their reading abilities. In addition, the integration of web-retrieved materials in teaching the reading skill was positively viewed by the participants since such materials led to the development of the reading skill with a progress in students' content knowledge and improvement in their reading competence.

Moreover, Chetsadanuwat (2018) investigated the English language needs of (63) Thai nurses. It was revealed that nurses had rated listening as the most required communicative skill since; for example, listening to a patient's history, symptoms, and requests' was the highly needed 


\section{Rehab Hamadtoh Abul-Ghait Gohar}

function. Nurses also indicated that skills of speaking, reading, and writing were highly needed in which asking patients about their complaints and symptoms, reading physician's orders and writing various medical reports were functions of great importance.

As with all higher education programs, nursing graduates need to be able to read critically and write in order to understand medical references, add notes to patients' charts, and participate in research studies as their nursing career develops. Reading, in particular, is a key nursing skill. Nurses need to be able to identify the major ideas, identify the author's purpose, recognize relevant supporting details, and assess patterns and trends in words and data (graphs, charts, and other forms of informational text). Furthermore, they need to draw appropriate conclusions and effectively apply the information and conclusions to their work on a daily basis. Accordingly, both low level and high or critical reading skills are of special importance to ESP students in general and nursing students in particular. In this concern, Akın, Koray and Tavukçu (2015) indicated that critical reading has a significant effect on the understanding of scientific and medical texts.

Critical reading is regarded as a crucial element for success in college as either an undergraduate or graduate student. Research has proved that considering reading as a transactional process is more effective than regarding it as a process of just decoding meanings of the text. However, recent approaches to teaching reading often recommend prioritizing the decoding of meaning over more active reading engagement. Assignments that explicitly or implicitly consider reading as determining correct interpretations risk reinforcing the frustration students experience as they struggle to interpret texts. Various approaches to critical reading instruction, based on research from the fields of educational psychology, literacy and developmental reading, argue that enhancing students' creative responses to authentic reading texts can help students gain the required persistence, and enjoyment for becoming attentive critical readers (Mickelson, 2018).

Critical reading and thinking are essential for academic achievement in higher education. To be successful, students should read extensively for getting knowledge and information from books, research articles, and other resources and think critically about what they have read. Albeckay (2014) indicated critical reading skills are of utmost importance for EFL students as they have close links to their competence in reading comprehension. Manarin (2015) described critical reading as reading for academic purposes, such as determining the major textual elements; 
A Proposed Infographics-Based ESP Course for Enhancing Graduate Nursing Major Students' critical Reading Skills and Motivation

distinguishing between main ideas and supporting details; evaluating the relevancy and adequacy of what is read and making judgments; and making relevant inferences and drawing conclusions. Besides, Thuy (2017) supported these critical reading functions and highlighted other critical reading skills such as reading in which a questioning attitude and a logical analysis are employed to interpret what is read; developing clear understanding of the writer's ideas and forming one's own opinion the reading text.

For teaching different reading skills, the following strategies are recommended for students to perform an efficient reading task (Vaezi, 2001 and Bouklikha, 2016):

- Pre-reading strategy prepares students to read efficiently; it facilitates comprehension since it is related to students' background through providing different activities such as brainstorming, guessing, and previewing titles and pictures.

- While-reading strategy allows students to be involved in the reading task with activities such as arguing, questioning, comparing the text with their own personal experience, scanning and skimming activities, working out the meaning of unfamiliar words, clarifying and predicting.

- Post-reading strategy involves different and varied activities such as group discussion, summarizing, questioning, filling out charts, evaluating a text and giving opinions, reading other related materials, reviewing the content, and working on grammar, vocabulary in context or word roots and discourse features.

Enhancing students' critical reading skills necessitates arousing their motivation since motivation is one of the affective factors that greatly influence language learning in general and reading in particular. Guthrie \& Wigfield (2000) stated that:

Motivational processes are the foundation for coordinating cognitive goals and strategies in reading. For example, if a person is intrinsically motivated to read and believes she is a capable reader, the person will persist in reading difficult texts and exert effort to resolve conflicts and integrate text with prior knowledge. A learner with high motivation will seek books known to provide satisfaction. The cognitive abilities needed to find 


\section{Rehab Hamadtoh Abul-Ghait Gohar}

books, avoid distraction while reading, and assimilate new ideas are activated if the text is fulfilling internal goals ... In sum, becoming an excellent, active reader involves attunement of motivational processes with cognitive and language processes in reading (p. 408).

The link between motivation and reading is critical and has been established through countless researchers. For example, Grabe and Stoller (2002) stressed the importance of reading motivation for learners as it supports learners' skills of reading and understanding texts easily. Accordingly, all English language learners need to enhance their reading motivation for a better understanding of written texts.

After a review of literature related to reading motivation, Ahmadi (2017) concluded that students with higher motivation in reading comprehension would advance more than others with lower motivation. Besides, explicit instruction of motivation was regarded as an active means to support students' reading comprehension and become good readers. Reading motivation can result in the development of language learning performance for various students' levels regardless of the learning context they are in.

Reading motivation can be either intrinsic or extrinsic. For distinguishing these two types, Schiefele, Schaffner, Möller and Wigfield (2012) emphasized that intrinsic reading motivation is regarded as the desire to read because the activity itself is satisfying or rewarding. In other words, intrinsic motivation to read can be either object or activity specific. In the case of object-specific intrinsic reading motivation, the learner is interested in the topic and; thus, s/he is motivated. In the case of activity-based intrinsic reading motivation, the learner is motivated to read due to the positive experiences provided by the activity, such as being attracted by a story. In contrast, extrinsic reading motivation refers to reasons for reading which are external to either the activity or the topic of the text. Andreassen and Bråten (2010) evaluated the relation between extrinsic and intrinsic motivation, and reading competence. The findings led to significant positive correlations between intrinsic motivation and comprehension. Extrinsic reading motivation did not contribute uniquely to performance in any of the comprehension tests, whereas intrinsic reading motivation was an effective predictor of text comprehension.

Furthermore, Retelsdorf, Köller, and Möller (2011) investigated the unique effects of reading motivation on reading comprehension. Indicators of intrinsic motivation (reading enjoyment, reading for interest), extrinsic motivation (competition), and reading self-concept 
A Proposed Infographics-Based ESP Course for Enhancing Graduate Nursing Major Students' critical Reading Skills and Motivation

were assessed. Results revealed that significant correlations with comprehension were only indicated for reading enjoyment. Reading for interest also had a significant correlation with comprehension but it was low, whereas competition was weakly and negatively associated with comprehension.

In order to provide an intrinsically motivating learning context to improve students' reading skills, using authentic materials side by side with pictures, charts, graphics to build a context of the texts in question is so beneficial, attractive and thus motivating.

In the modern world, technology provides a new dimension of reading since screen pages have dominated the way of learning. Kress (2003) stressed this by stating that:

The screen is now the dominant site of texts; it is the site which shapes the imagination of the current generation around communication. The screen is the site of the visual, of the image. This does not mean that writing cannot appear on the screen, but when it does, it will be appearing there subordinated to the logic of the visual. This will have many consequences: reading will increasingly proceed in terms of the application of the logic of the image to writing (pp. 166-167).

In the same vein, Gee (2007) indicated that language is not the only means of communicational. Visual symbols such as images, graphs and artifacts are of particular significance. In newspapers and magazines as well as in textbooks, images occupy more and more of the space alongside words. In fact, in most high school and university textbooks, images not only take up more space, they reflect meanings independent of the words in the written text. If the learner cannot read these images, s/he will not be able to deduce their meanings from the words. In such multimodal texts (texts that mix words and images), the graphs and images often convey different things from the words. And the combination of the two modes communicates ideas that neither of the modes does separately.

Since teachers are always suffering for gaining their students' attention, the inclusion of images, pictures, and visual tools to help students pay attention consciously is highly recommended. Therefore, infographics might be the good solution. Infographics are an increasingly 
popular approach to delivering content in a visual manner. Learners acquire knowledge and remember information easily and effectively by integrating both texts and visuals than through texts alone.

Davis and Quinn (2018) illustrated that since the beginning of recorded time, people have been using pictures and drawings to communicate and interact with each other. Sumerians used pictographs for record-keeping purposes, and Egyptians used hieroglyphics to capture their history. Infographics are written artifacts about collected data in a dynamic visual format. An infographic can be described as graphic design that integrates data visualizations, illustrations, text, and images together into a format that reflects a comprehensive description and provides easy and understandable information about a topic to the readers (Toth, 2013 and Krum (2014). Accordingly, information can be effectively presented with a minimum explanation, and at the same time, the relationships of the content can be conveyed clearly through using infographics. In this concern, Yildirim (2017) stated that since infographics can easily present extensive information, they can be used to serve other purposes such as reminding the available information, showing the relationship between concepts, transfer of processes and events, presentation of course content and summarizing the information obtained.

Bradshaw and Porter (2017) also regarded infographics as visual translation of information and data organized in a style that tells a story. Since the majority of people, approximately 65\%, are visual learners, most students prefer studying through visual information; thus, teachers must be intelligent in selecting, creating, and using visuals effectively. Other additional aspects for using such visual media include information burden, learner disengagement, and the widespread use of mobile devices. For example, when trying to integrate the use of mobiles and tablets to facilitate learning, faculty should appreciate that information can be more compatible when it is "scrolled" or "swiped," which is easily facilitated with infographics. The use of infographics fosters the movement to a more visual, mobile-friendly medium.

Effective infographics illustrate varied relationships through employing visual representations to communicate content within context. Thus, there are different design formats for infographics; for instance, if the infographic reflects a sequential progress such as change over time, a linear structure is recommended to lay out visual elements. As a result, educators can use a graph that explains (a) flow (e.g., flowchart) to show process; (b) structure (e.g., hierarchical chart) to present classification; (c) cluster (e.g., Venn diagram) to convey grouping relationships; (d) radiate 
A Proposed Infographics-Based ESP Course for Enhancing Graduate Nursing Major Students' critical Reading Skills and Motivation

(e.g., concept map) to facilitate connections between links and nodes; (e) pictorial (e.g., road map) to illustrate realistic concepts; and (f) display (e.g., bar chart) to compare and contrast or cause and effect (Duarte 2008).

For designing infographics, various criteria should be taken into considerations. For example, Lamb and Jhonson (2014) proposed some basic criteria of infographics design including that they should be: simple illustrating complex information quickly and clearly, integrating visuals and texts, and self-explanatory and attractive for readers. Besides, Dunlap and Lowenthal (2016) reported on an evaluation of top twenty "liked" infographics on a popular infographic sharing website for better understanding of what makes an effective infographic in order to better qualify graduate students as consumers and designers of infographics. Their review concluded with recommendations and techniques on how educators might leverage the use of infographics in their classrooms. Aesthetic learning experiences were employed to deduce the situational qualities or guidelines for designing appropriate infographics. The basic guidelines for designing infographics were identified as: immediacy, malleability, compellingness, resonance and coherence. In addition, Bradshaw and Porter (2017) reported that developing an infographic requires a content expert who can determine the audience and what information to convey. Effective infographics should (1) have a title; (2) include a storyline complete with a beginning, middle, and end; (3) follow design principles related to color, font, balance, and consistency of shapes; (4) use copyright-free images; and (5) guide the audience to additional information.

Several studies were experimented to investigate the use of infographics for improving learners' various skills. For example, Noh et al. (2014) examined the use of infographics as a tool for facilitating learning among graphic design and digital media students. Findings revealed that all infographic features including images and symbols, attractive colors, concise texts and diagrams could enhance learners' comprehension of the delivered information. Finally, the participants highly appreciated using infographics due to making information concise and coherent, enhancing creativity and productivity, and improving comprehension and concentration in the learning sessions. However, the findings suggested that the lack of proper guidelines and standards in the design of infographics might lead to various problems to be encountered by learners. 


\section{Rehab Hamadtoh Abul-Ghait Gohar}

Dyjur and Li (2015) applied an infographics assignment in a Master's level course, designed to develop students' $21^{\text {st }}$ century skills while employing an instructional design framework and enhancing technical skills. Most students in the course reported that the assignment was an effective learning experience that motivated them to think about how a message can be illustrated visually. In addition, infographics developed their critical analysis ability and fostered their visual literacy skills.

Furthermore, Alrwele (2017) investigated whether the use of infographics results in significant differences in university female students' achievement and explored students' perceptions of the infographics' impact. Data were collected using achievement tests and a questionnaire assessing students' perceptions. The results revealed significantly higher achievement in the experimental group than in the control group. Almost $90 \%$ of the participants in the experimental group reported that infographics had a positive impact on their intellectual life skills and affective development.

Fadzil (2018) attempted to explore pre-service science teachers' perceptions of the use of infographics. The participants of the study were required to individually design an infographic based on the upper secondary school science curriculum. The findings proved that the preservice teachers reported positive comments about the infographics assignment. It was also indicated that when the pre-service teachers were involved in the learning process, they had a sense of independence for their own learning. Furthermore, it was concluded that developing infographics supports innovations in teaching and learning and that infographics can be considered as an appropriate tool for enhancing understanding of conceptual knowledge and improving various critical reading and thinking skills.

In the era of language teaching, few research was conducted to experiment the use of infographics with different linguistic skills; however, some studies indicated that infographics can support reading comprehension and writing skills while sharpening critical thinking and synthesizing skills. For example, Manowong (2017) conducted an action research to examine EFL learners' reading and learning experiences through using online tools in a face-to-face EFL classroom. Infographics were used as the main learning assignment along with other online tools: Padlet, Google Docs, and Canva to promote English reading for EFL learners. Students' reflections and questionnaires were used to collect the required data. The findings revealed that students' experiences when reading English were enhanced; the use of infographics was regarded as 
A Proposed Infographics-Based ESP Course for Enhancing Graduate Nursing Major Students' critical Reading Skills and Motivation

motivating; and the easy-to-read visual texts enabled them to understand the assigned reading topics much easier. In addition, the infographic assignments incorporating the use of online tools encouraged them to actively participate in the English reading activities in a collaborative atmosphere while allowing them to exercise their creativity and develop positive attitudes toward the supportive role of technological tools in educational settings.

Besides, Dahmash, Al-Hamid and Alrajhi (2017) investigated the impact of using information graphics on the teaching of linguistics for 186 Saudi female college students at the College of Languages in Princess Nourah bint Abdulrahman University (PNU). Students were required to design infographics as a project in two linguistic courses: Introduction to Linguistics and Introduction to Semantics. The findings reflected students' positive attitude towards using infographics even though the majority were not familiar with them. While creating infographics, the participants found practicing various skills such as higher thinking skills and collaborative learning beneficial. They were also motivated to utilize infographics in their future academic and professional careers.

Furthermore, Sukerti, Yuliantini and Susana (2018) analyzed students' perceptions in completing essay and infographic project through PBL (project-based learning). Essay and infographic were the final products of the project in which the essay was used as the main reference to design infographics containing visually attractive elements such as images, graphs and tables. Those final products were uploaded into students' social media to get feedback from a wider range of audience. Participants were 64 second semester students enrolled in a three-year undergraduate program in Informatics Management. The results revealed that students experienced deep and autonomous learning through the stages conducted in the project. They gained better understanding on grammar and vocabulary during peer review and showed positive attitude in designing infographics as they could revise the structure of their essay while designing the infographics' frames. Consequently, the projectbased learning in writing essay and designing infographics helped to enhance students' engagement and foster their collaborative and communicative skills while working together in groups.

Based on the previously stated review, using infographic can be a unique way to present synthesized information in a visual format. Effective infographics are engaging, create interest, and lead the audience 
to more information. Many research recommendations support the need for educators to consider infographic utilization in their teaching since it evokes emotions and creates an experience, which can provoke action through conveying concise information, and leading the audience to a next step or further information seeking in an interesting way.

\section{Statement of the problem}

Based on the previous review of literature in addition to the researcher's direct contact with specialized nursing diploma students for more than four years teaching them several English courses, the problem of the current research was stated as "the need of the graduate nursing students to enhance their critical reading skills and motivation". Since using infographics is highly recommended to improve learners' critical reading and thinking; a proposed infographics-based ESP course was designed and used for enhancing those students' critical reading skills and motivation towards reading.

\section{Questions of the Study}

The present study answered the following questions:

1. What are the critical reading skills necessary for graduate nursing major students?

2. What are the criteria of designing effective infographics?

3. What are the features of the proposed infographics-based ESP course for enhancing graduate nursing major students' critical reading skills and motivation?

4. What is the effect of the proposed infographics-based ESP course on enhancing graduate nursing students' critical reading skills?

5. What is the effect of the proposed infographics-based ESP course on enhancing graduate nursing students' motivation towards reading?

\section{Purpose}

The present study aimed at assessing the effectiveness of a proposed infographics-based ESP course in enhancing graduate nursing major students' critical reading skills and motivation towards either reading or reading with infographics.

\section{Delimitations}

The study was delimited to the following:

1. A sample of students enrolled in the second year of the specialized nursing diploma, Faculty of Nursing, Mansoura University.

2. EFL critical reading skills necessary for graduate nursing major 
A Proposed Infographics-Based ESP Course for Enhancing Graduate Nursing Major Students' critical Reading Skills and Motivation

students (identifying the author's purpose, determining cause and effect relationships, distinguishing between facts and opinions, drawing conclusions and making inferences, outlining and summarizing, comparing and contrasting and evaluating an argument). Those skills were identified according to analyzing the needs of the target participants.

3. Employing web 0.2 tools (Facebook, Padlet and Piktochart) while using infographics for designing and implementing the proposed ESP course.

\section{Operational definition of terms}

\section{ESP (English for Specific Purposes)}

ESP is an active branch of Applied Linguistics in general, and of Teaching English as a Foreign Language (TEFL) in particular. It refers to teaching English to learners of a particular specialty or people already in employment; with special focus on the particular vocabulary and skills they need. A given course of ESP focuses on one occupation or profession, such as Technical English, Scientific English, English for medical professionals, English for nursing, English for tourism, and so on.

\section{Critical reading skills}

Critical reading refers to applying critical thinking skills to a written text by analyzing and evaluating what is read. Important foundations for critically interpreting a text include understanding the writer's purpose, distinguishing facts and opinions, determining cause and effect relationships, drawing conclusions and making inferences, outlining and summarizing, and comparing and contrasting.

\section{Motivation}

Motivation is a desire or feeling that always provides positivism to students and pushes them to fulfill an EFL reading task or activity successfully no matter how hard and tough it is since students are powered to achieve high levels of critical thinking and reading.

\section{Infographics}

An infographic is an integration of the words "information" and "graphics" to combine the data into a graphical design. In other words, it reflects a representation of information in a graphic format. Infographics allow readers to understand the information more easily and to analyze the text critically as they combine texts, images, and other visual elements 
to help readers focus on essential facts.

\section{Hypotheses:}

The present study tested the following hypotheses:

1. There is a statistically significant difference at 0.05 level between the mean scores of the control group and the experimental group on the post administration of the critical reading skills test in favor of the experimental group.

2. There is a statistically significant difference at 0.05 level between the mean scores of the experimental group pre-post administration of the critical reading skills test in favor of the post administration.

3 . There is a statistically significant difference at 0.05 level between the mean scores of the control group and the experimental group on the post administration of the motivation scale in favor of the experimental group.

4. There is a statistically significant difference at 0.05 level between the mean scores of the experimental group pre-post administration of the motivation scale in favor of the post administration.

5. The effectiveness of the proposed infographics-based ESP course in developing students' critical reading skills is more than (1.2) when measured by Black's modified gain percentage and more than (0.6) when measured by Mac Gogian's effectiveness percentage.

6. The effectiveness of the proposed infographics-based ESP in developing students' reading motivation is more than (1.2) when measured by Black's modified gain percentage and more than (0.6) when measured by Mac Gogian's effectiveness percentage.

\section{Method of the research}

\section{Participants}

The experiment involved the participation of one hundred students enrolled in the second year of the specialized nursing diploma, Faculty of Nursing, Mansoura University. They were assigned into two groups one control and one experimental; each group included fifty students.

\section{Design}

The study adopted the quasi-experimental design using two groups: an experimental and a control group. The experimental group studied through the proposed ESP course using infographics, while the control group received the regular English course. Both groups received the pre- 
A Proposed Infographics-Based ESP Course for Enhancing Graduate Nursing Major Students' critical Reading Skills and Motivation

and post-application of the critical reading skills test and the motivation scale.

\section{Procedures}

\section{First, designing the instruments of the study}

A. The critical reading skills questionnaire

A questionnaire was designed for identifying the English critical reading skills necessary for graduate nursing major students. The skills in the questionnaire were adapted based on reviewing literature related to ESP and critical reading skills required from nursing students. The initial form of that questionnaire (see appendix 1) was presented to some EFL specialists to check its validity. The questionnaire was also distributed to thirty second year specialized diploma nursing students in order to identify their reading needs. The purpose of the research was explained and clarified to those students before distributing the questionnaire.

Based on the EFL specialists' comments as well as the students' responses to the questionnaire, some necessary modifications were made and the final list of the critical reading skills necessary for graduate nursing ESP students comprised the following:

1. Identifying the author's purpose

2. Determining cause and effect relationships

3. Distinguishing between facts and opinions

4. Drawing conclusions and making inferences

5. Outlining and summarizing

6. Comparing and contrasting

7. Evaluating an argument

B. The criteria checklist for selecting and designing the reading infographics

In order to design or select appropriate infographics to be employed in the content of the proposed ESP course, some criteria or guidelines were adapted from Parrish's Aesthetic principles for instructional design (2009) and Dunlap \& Lowenthal (2016). The checklist was presented to some specialists in instructional technology to assess its validity. The final version of the infographic design criteria is presented in (appendix 2); those criteria are categorized in the following five main domains:

- Immediacy: this reflects the infographic's ability to engage students directly in the content in order for them to be excited and 
interested through using clear examples and visual illustrations of complex concepts and ideas.

- Malleability: this allows learners to identify personal meaning and relevance, and to be co-owner/co-creator of the experience. An infographic can be malleable by motivating students to interact with the content (e.g., asking questions for enhancing students' reflection, allowing them to access the infographic in more than one way, providing effective content pathways).

- Compellingness: this means that infographic is irresistible that it evokes learners' interest, attention, and admiration by, for example, sharing provocative or novel ideas or problems. Another means for an infographic to be compelling is to employ a narrative structure that motivates the student through the content for finding out what happens next.

- Resonance: an infographic is resonant when its images, emotions, and memories enables students to form relations and connections. Using storytelling as well as visual images that reflect connections can help an infographic resonate for students.

- Coherence: this addresses logic, clarity and consistency of the infographic. A coherent infographic is one that presents a complete and well-formed message. Without coherence, an infographic can be disjointed, which might negatively affect students' ability to deduce meanings from the infographic.

\section{The critical reading skills test:}

A critical reading skills test was designed for: identifying the homogeneity level of the control and experimental groups, and determining the participants' pre-and post-levels in the target critical reading skills which were previously identified. The test items were specified to ensure that each skill is addressed and measured. When stating the questions, it was important to ensure that the texts are appropriate to the language level of the target students; and the instructions and wording of the test are explicitly and clearly stated to help the students' reach the correct response.

The critical reading skills test consisted of two texts, fourteen multiple choice items per text; thus the total test items are twenty-eight items aiming at measuring the seven target critical reading skills. To establish the validity of the test, it was given to a number of TEFL specialists to evaluate the questions in terms of covering the target skills, 
A Proposed Infographics-Based ESP Course for Enhancing Graduate Nursing Major Students' critical Reading Skills and Motivation

appropriateness to the participants and clarity of the language used. The jurors provided their points of view indicating that the test measures the target critical reading skills and reflects high level of critical thinking. Some of the test items addressing the summarization and evaluation skills were restated linguistically based on jurors' recommendations.

Reliability of the critical reading skills test was estimated through getting the coefficient of internal consistency ( $\alpha$ Cronbach). Thirty students other than the main participants of the experimental and control groups were selected to be the piloting sample. The value of ( $\alpha$ Cronbach) reflects that the total test reliability is $(0 . \wedge \mathrm{V})$. This indicates that the critical reading skills test is reliable and can be administered as one of the research instruments. The final version of the test is presented in (appendix 3).

\section{The motivation scale:}

The motivation scale was designed for assessing graduate nursing students' motivation towards reading before and after conducting the experimental treatment. The scale consisted of twenty items; a 5-point Likert scale (1) strongly disagree, (2) disagree, (3) neutral, (4) agree, and (5) strongly agree) was used. To assess how valid is the scale, it was presented to a number of TEFL specialists and psychologists to evaluate the statements in terms of the appropriateness and clarity of the statements. The jurors provided their points of view indicating that the scale is clear and appropriate to assess students' motivation towards reading and infographics.

Reliability of the motivation scale was assessed through administering it to a pilot sample of thirty graduate nursing students. The value of Cronbach's Alpha coefficient calculated for the motivation scale is 69.8 which reflects that the reliability of the scale is fairly accepted. The final version of the motivation scale is presented in (appendix 4).

\section{Second, designing the proposed infographics-based ESP course:}

An integrated approach for ESP course design was adopted through following a sequence of steps: needs analysis, design (syllabus, materials, methodology), implementation/teaching and evaluation. These phases are illustrated as follows:

1. Needs analysis: this phase included studying and analyzing the target linguistic needs of the participants in addition to their learning needs. Reviewing literature related to ESP revealed that 


\section{Rehab Hamadtoh Abul-Ghait Gohar}

nurses need various reading skills. A reading questionnaire was distributed to thirty graduate nursing major students to determine their needs regarding the required critical reading skills. Analyzing their responses indicated that they are in dire need to develop some critical reading skills (namely, Identifying the author's purpose, determining cause and effect relationships, distinguishing between facts and opinions, drawing conclusions, making inferences, outlining and summarizing, and evaluating an argument). They mentioned that they need such skills to maximize their benefit of reading medical references for improving their nursing career and supporting their graduate study. Regarding their learning needs, those students need to be highly motivated through creating a learning environment which is enjoyable, fulfilling, manageable, and generative.

2. Syllabus design: this phase included the procedures followed in the design of the proposed ESP course using infographics. These procedures started with identifying the objectives of the ESP course, content design, materials design, methodology, and evaluation. These procedures are explained as follows:

2-1. Target objectives of the ESP course were identified as:

-Proficiency objectives targeting the mastery of the critical reading skills previously identified through administering a questionnaire aiming at analyzing the needs of the graduate nursing students.

-Affective objectives targeting the development of students' motivation towards reading.

2-2. Content: the content of the ESP course was presented in eight sessions other than the orientation session. The content included authentic reading texts and reading infographics with multiple critical reading tasks and activities. For designing the syllabus of the ESP course, certain criteria were taken into consideration:

-Learnability: organizing the content of each session in a gradual manner (starting with the regular reading skills to the advanced critical reading tasks) to be more efficient.

- Coverage: incorporating the vocabulary and structures that have wider coverage in students' specialization.

-Usefulness: focusing on the forms and skills of the language that are socially required and useful for the students.

2-3. Materials and experiences: authentic materials were employed 
A Proposed Infographics-Based ESP Course for Enhancing Graduate Nursing Major Students' critical Reading Skills and Motivation

in the design of the ESP course; as genuine/authentic reading texts and infographics were provided in each session in order for students to practice the target critical reading skills. The topics chosen were closely related to the medical field and particularly nursing. Those authentic materials were a major source of students' motivation and were chosen according to three criteria: first, readability which refers to the appropriateness of the vocabulary and syntax used so as not to demotivate the students; second, coping with students' linguistic and learning needs; and third, considering students' interests.

employed:

Throughout the ESP course, the following tools were

-Infographics: the first four sessions were presented with the use of interactive infographics reflecting a representation of the main phases of each session and information in a graphic format. They allowed readers to understand the information more easily as they combine texts, images, and other visual elements to help readers to focus on essential facts. In the other four sessions, regular texts were presented in which students were asked to transform them into infographics.

-Piktochart: is a free graphic design tool website available on https://piktochart.com/. It was selected for the students to design and create their own infographics responding to some assigned reading tasks in a creative and motivating way.

-Padlet wall: was used for whole-class engagement and students' infographics exhibitions.

-Facebook: A Facebook group was created for posting the sessions' infographics and reading texts and for the students to socialize and stay connected. Students can also receive feedback and communicate with the instructor personally through Facebook messenger.

2-4. Methodology: different reading strategies in which tasks and activities reflecting the students' specialist areas were employed in the ESP course. Those reading strategies were regrouped in pre-reading, while-reading and post-reading strategies as illustrated in the following table. 
Table 1.

Reading strategies employed throughout each session

Phase

Reading strategies

Pre-reading Preview the text by thinking about: the title, subtitles and images.

Activate students' prior knowledge about the topic.

Use tables, figures, and pictures combined with the text to increase understanding.

Ask guiding questions about the infographic/text before reading it.

Regulate mood to stimulate the reading process.

While- Skim and scan the infographic for information.

reading Underline or circle information in the reading infographic/text to highlight important information.

Stop reading to check understanding.

Use context clues to enhance understanding.

Check comprehension when coming across conflicting information.

Reread the problematic part.

Guess the meaning of unknown words or phrases.

Check the dictionary for the meaning of the unknown words (online).

Post- Answer comprehension questions.

reading Summarize to reflect on the text's major ideas.

Inference and conclude.

Compare and contrast information from one or more texts.

Analyze and evaluate the information presented in the reading infographic/text.

Design an infographic (by collaborative groups) to reflect critical understanding of the text.

Note. Adapted from Bouklikha (2016)

2-5. Evaluation: students (in groups) were asked to either design an infographic or make a summary based on what they understood responding to an assigned task of a given authentic nursing text or infographic. In addition, they were asked to keep a language-learning log to reflect on their study of each session. Thus, during the subsequent planning sessions, the logs were analyzed and several activities were designed to 
A Proposed Infographics-Based ESP Course for Enhancing Graduate Nursing Major Students' critical Reading Skills and Motivation

provide feedback accordingly.

The proposed infographics-based ESP course is presented in appendix 5.

\section{The experimental intervention:}

An equivalent group design with one experimental group and one control group was used in the present study. The following steps were followed:

\section{- Pre-intervention}

The specialized diploma nursing students' critical reading skills and motivation were assessed before conducting the experimental treatment at the start of the second semester of the academic year 2017/2018. Homogeneity between participants of the control and the experimental groups was established through administering the critical reading skills test and motivation scale to both groups before administering the experimental treatment. Table (2) shows whether there is any significant difference between the control and experimental groups concerning the test pre-administration.

\section{Table 2.}

Establishing homogeneity of the control and experimental groups the critical reading skills test

\begin{tabular}{|c|c|c|c|c|c|c|c|}
\hline Skills & Group & $N$ & Mean & $S D$ & $t$ & $\begin{array}{c}D f \\
(\mathrm{n} 1+\mathrm{n} 2- \\
2)\end{array}$ & $\begin{array}{c}\text { Sig. (2- } \\
\text { tailed) }\end{array}$ \\
\hline Identify & Exp. & 50 & .8600 & .67036 & \multirow[b]{4}{*}{0.8} & \multirow{8}{*}{98} & \multirow{8}{*}{$\begin{array}{c}\text { Not } \\
\text { Significant }\end{array}$} \\
\hline $\begin{array}{l}\text { author's } \\
\text { purpose }\end{array}$ & Control & 50 & 1.0600 & .73983 & & & \\
\hline \multirow{2}{*}{$\begin{array}{l}\text { Determine } \\
\text { cause and } \\
\text { effect } \\
\text { relationship }\end{array}$} & Exp. & 50 & .9600 & .85619 & & & \\
\hline & Control & 50 & 1.0800 & .72393 & & & \\
\hline \multirow{2}{*}{$\begin{array}{l}\text { Distinguish } \\
\text { between } \\
\text { facts and } \\
\text { opinions }\end{array}$} & Exp. & 50 & 1.1200 & .84853 & \multirow[b]{2}{*}{0.8} & & \\
\hline & Control & 50 & 1.2400 & .71600 & & & \\
\hline \multirow{2}{*}{$\begin{array}{l}\text { Inference } \\
\text { and } \\
\text { conclude }\end{array}$} & Exp. & 50 & 1.2200 & .81541 & \multirow[b]{2}{*}{0.5} & & \\
\hline & Control & 50 & 1.3000 & .83910. & & & \\
\hline
\end{tabular}




\section{Rehab Hamadtoh Abul-Ghait Gohar}

\begin{tabular}{cccccc}
\hline \multirow{2}{*}{ Summarize } & Exp. & 50 & .9200 & .75160 & \multirow{2}{*}{0.14} \\
\cline { 2 - 5 } & Control & 50 & .9400 & .68243 & \\
\hline \multirow{2}{*}{$\begin{array}{c}\text { Compare } \\
\text { and } \\
\text { contrast }\end{array}$} & Exp. & 50 & .9200 & .75160 & \\
\cline { 2 - 5 } & Control & 50 & .9800 & .82040 & 0.4 \\
\hline \multirow{2}{*}{ Evaluate } & Exp. & 50 & .9400 & .81841 & \multirow{2}{*}{0.13} \\
\cline { 2 - 5 } & Control & 50 & .9200 & .66517 & \\
\hline \multirow{2}{*}{ Total } & Exp. & 50 & 6.9400 & 2.06437 & \multirow{2}{*}{1.5} \\
\cline { 2 - 5 } & Control & 50 & 7.5200 & 1.87617 &
\end{tabular}

The above table indicates that $t$-value is not significant in each one of the critical reading skills and in the total score of the test; this proves that there was no significant difference between the control and experimental groups on the pre-test. In other words, the two groups were equivalent in their critical reading skills before conducting the experimental treatment.

Concerning the motivation scale, the following table shows the results of its pre-administration to the control and experimental groups.

Table 3.

Establishing homogeneity of the control and experimental groups on the motivation scale

\begin{tabular}{|c|c|c|c|c|c|c|c|}
\hline $\begin{array}{l}\text { Motivation } \\
\text { scale }\end{array}$ & Group & $N$ & Mean & $S D$ & $t$ & $\begin{array}{c}D f \\
(\mathrm{n} 1+\mathrm{n} 2- \\
2)\end{array}$ & $\begin{array}{c}\text { Sig. (2- } \\
\text { tailed) }\end{array}$ \\
\hline \multirow{2}{*}{$\begin{array}{l}\text { Towards } \\
\text { reading }\end{array}$} & Exp. & 50 & 53.9400 & .79308 & \multirow{2}{*}{0.14} & \multirow{2}{*}{98} & Not \\
\hline & Control & 50 & 53.9600 & .66884 & & & Significant \\
\hline
\end{tabular}

Table (3) shows that $t$-value is not significant for students' motivation towards reading which reflects that there was no statistically significant difference between the experimental and control groups on the pre-administration of the motivation scale. In other words, the homogeneity of the two groups was indicated regarding their motivation towards reading.

\section{- The intervention}

The proposed ESP course was administered to graduate nursing major students of the experimental group. The control group studied the regular English course. The experimental treatment was conducted throughout the second semester of the academic year 2017/2018. Procedures of the experimental treatment were:

$\checkmark$ An orientation session was conducted to the target experimental 
A Proposed Infographics-Based ESP Course for Enhancing Graduate Nursing Major Students' critical Reading Skills and Motivation

participants to raise their awareness concerning the ESP course; its objectives and phases of each session. This session aimed also at familiarizing those students with the critical reading skills which are the target of the course. Students were told that they will study the course in a blended manner (face-to-face and online). Besides, they were trained on how to create an infographic using Piktochart, and then post it on Padlet.

$\checkmark$ For designing how the students proceed in each session, A Facebook group was created to gather all the students in the experimental group. In each session, a reading infographic or the regular text (following the pre-while-post phases and strategies of teaching critical reading) is posted to the Facebook group. The students worked in groups and accessed the session's infographic using their smart phones or tablets. This enabled the students to zoom in or out the graph and follow the preplanned phases of the session while maintaining active discussions with the instructor and collaborating with their peers. The following figure is an infographic of one of the critical reading sessions.

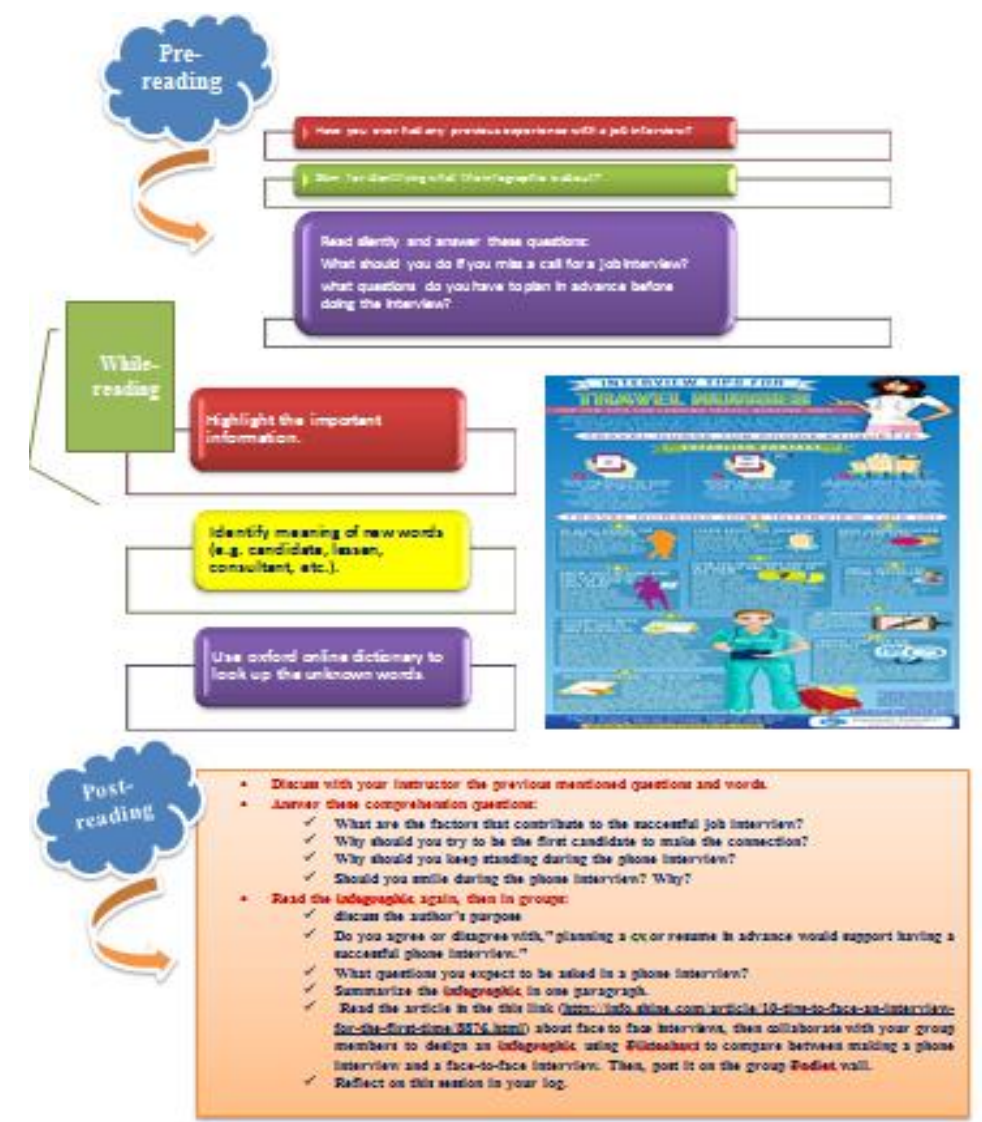

Figure 1. An infographic of a critical reading lesson 
The treatment included the implementation of eight sessions in addition to the orientation session. Students follow the same phases in all sessions. However, the final task or phase was not the same in the eight sessions; since in the first four sessions, students were asked to transform the reading infographic into a regular text summarizing the main points they understood in the assigned infographic; and in the next four sessions, the task was reversed as a regular reading text was provided and students were required to transform it int an infographic illustrating the key ideas in the text. The following figure illustrates a screen shot of the Padlet wall with some infographics published and used by the students.

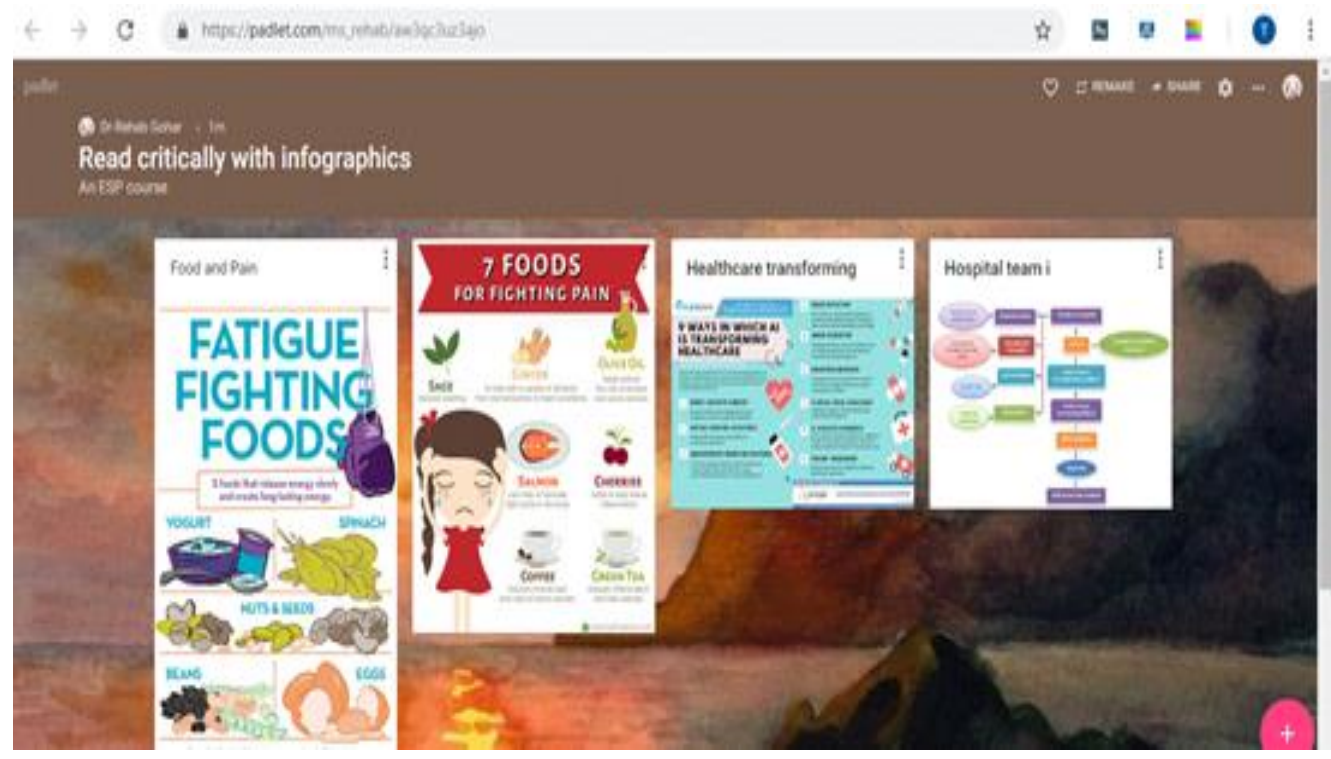

Figure 2. Screen shot of the Padlet wall

\section{- Post- intervention}

The post-administration of the instruments (the critical reading skills test and motivation scale) was conducted after the experimental treatment to examine the improvement in the students' critical reading and motivation levels for both the control and experimental groups.

\section{Results}

\section{Testing the first hypothesis}

$t$-test for independent samples was used to test the first hypothesis which is" There is a statistically significant difference at 0.05 level between the mean scores of the control group and the experimental group on the post administration of the critical reading skills test in favor of the experimental group". The following table illustrates the results: 
A Proposed Infographics-Based ESP Course for Enhancing Graduate Nursing Major Students' critical Reading Skills and Motivation

\section{Table 4.}

Comparing performance of the control and experimental groups on the post-administration of the critical reading skills test

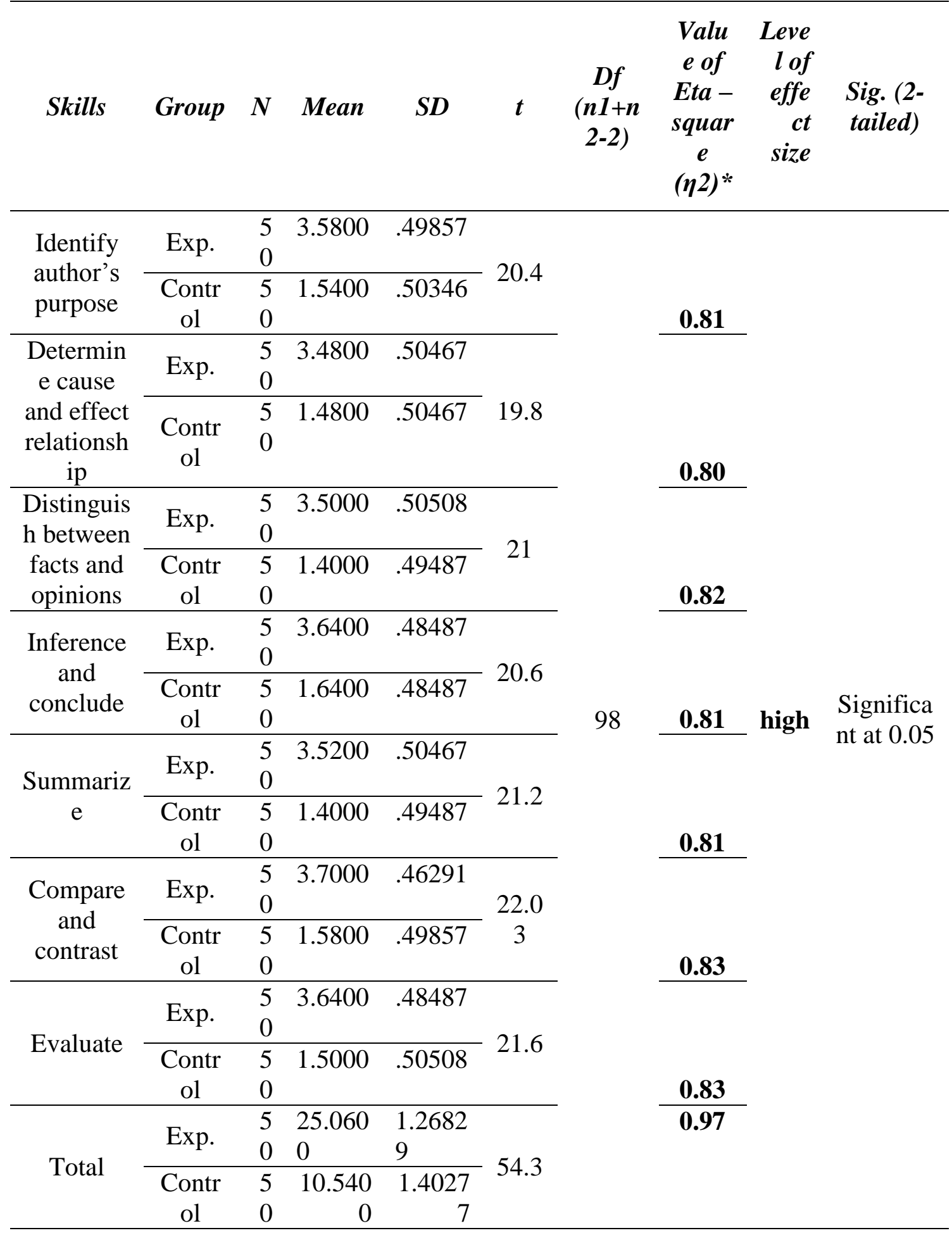

Table (4) shows that the mean scores of the experimental group students in the seven critical reading skills and in the total are higher than 


\section{Rehab Hamadtoh Abul-Ghait Gohar}

those of the control group. In addition, all $t$-values are significant at .05 level which reflects that there is a statistically significant difference between the experimental and control groups in the individual skills and in the total score on the post-administration of the test in favor of the experimental group. In other words, the experimental group students outperformed their counterparts of the control group in their critical reading skills. Moreover, the previous table illustrates that the levels of the effect size of the proposed ESP course using infographics on the critical reading skills of the experimental group students in comparison to those of the control group are high. Accordingly, since $t$-values in addition to the effect size enhance the positive effect of the ESP course on student' critical reading skills, the first hypothesis of the study is proved and accepted.

\section{Testing the second hypothesis}

$t$-test for dependent samples was used to test the second hypothesis which addressed the difference between the experimental group pre- and post-administration of the critical reading skills test. Results are shown in the following table.

Table (5).

Comparing the pre-post performance of the experimental group on the critical reading skills test

\begin{tabular}{|c|c|c|c|c|c|c|c|}
\hline Skills & $\begin{array}{c}\text { Measure- } \\
\text { ment }\end{array}$ & $N$ & Mean & $S D$ & $t$ & $\begin{array}{l}\text { D. } f(n- \\
1)\end{array}$ & Sig. (2-tailed) \\
\hline \multirow{2}{*}{ Identify author's purpose } & Pre & 50 & .8600 & . 67036 & \multirow{2}{*}{23.77} & \multirow{16}{*}{49} & \multirow{16}{*}{$\begin{array}{c}\text { Significant at } \\
0.05\end{array}$} \\
\hline & Post & 50 & 3.5800 & . 49857. & & & \\
\hline \multirow{2}{*}{$\begin{array}{l}\text { Determine cause and effect } \\
\text { relationship }\end{array}$} & Pre & 50 & .9600 & .85619 & \multirow{2}{*}{26.3} & & \\
\hline & Post & 50 & 3.4800 & .50467 & & & \\
\hline \multirow{2}{*}{$\begin{array}{c}\text { Distinguish between facts and } \\
\text { opinions }\end{array}$} & Pre & 50 & 1.1200 & .84853 & \multirow{2}{*}{27.9} & & \\
\hline & Post & 50 & 3.5000 & .50508 & & & \\
\hline \multirow{2}{*}{ Inference and conclude } & Pre & 50 & 1.2200 & .81541 & \multirow{2}{*}{26.7} & & \\
\hline & Post & 50 & 3.6400 & .48487 & & & \\
\hline \multirow{2}{*}{ Summarize } & Pre & 50 & .9200 & .75160 & \multirow{2}{*}{22.8} & & \\
\hline & Post & 50 & 3.5200 & .50467 & & & \\
\hline \multirow{2}{*}{ Compare and contrast } & Pre & 50 & .9200 & .75160 & \multirow{2}{*}{25.7} & & \\
\hline & Post & 50 & 3.7000 & .46291 & & & \\
\hline \multirow{2}{*}{ Evaluate } & Pre & 50 & .9400 & .81841 & \multirow{2}{*}{28.2} & & \\
\hline & Post & 50 & 3.6400 & .48487 & & & \\
\hline \multirow{2}{*}{ Total } & Pre & 50 & 6.9400 & 2.06437 & \multirow{2}{*}{71.1} & & \\
\hline & Post & 50 & 25.0600 & 1.26829 & & & \\
\hline
\end{tabular}


A Proposed Infographics-Based ESP Course for Enhancing Graduate Nursing Major Students' critical Reading Skills and Motivation

Results shown in the above table illustrate that the $t$-value is significant at 0.05 level for each particular skill and the total score. This reflects the statistically significant difference between the mean scores of the experimental group's pre-post-administration of the critical reading skills test in favor of the post-administration due to using the proposed infographics-based ESP course. Consequently, the second hypothesis of the research is considered accepted.

\section{Testing the third hypothesis}

Results of testing the third hypothesis which handled the difference between the mean scores of the control group and those of the experimental group on the post administration of the motivation scale are shown in the following table.

Table 6.

Comparing scores of the control and experimental groups on the post administration of the motivation scale

\begin{tabular}{|c|c|c|c|c|c|c|c|c|c|}
\hline $\begin{array}{l}\text { Motivation } \\
\text { scale }\end{array}$ & Group & $N$ & Mean & $S D$ & $t$ & $\begin{array}{c}D f \\
(n 1+n 2- \\
2)\end{array}$ & $\begin{array}{c}\text { Value } \\
\text { of Eta- } \\
\text { square } \\
(\eta 2)^{*}\end{array}$ & $\begin{array}{r}\text { Level } \\
\text { of } \\
\text { effect } \\
\text { size } \\
\end{array}$ & $\begin{array}{l}\text { Sig. }(2- \\
\text { tailed })\end{array}$ \\
\hline \multirow{2}{*}{$\begin{array}{l}\text { Towards } \\
\text { reading }\end{array}$} & Exp. & 50 & 85.3000 & 3.18959 & \multirow{2}{*}{10.3} & \multirow{2}{*}{98} & & \multirow{2}{*}{ high } & \multirow{2}{*}{$\begin{array}{l}\text { Significant } \\
\text { at } 0.05\end{array}$} \\
\hline & Control & 50 & 66.5200 & 12.43963 & & & 0.52 & & \\
\hline
\end{tabular}

Results of $t$-test for independent groups presented in the previous table indicate that $t$-value is significant at .05 level which proves that there is a statistically significant difference between the control and experimental groups on the post-administration of the motivation scale in favor of the experimental group. Besides, value of effect size of the proposed infographics-based ESP course on students' motivation towards reading $(\eta 2=0.52)$ is high. Such a result emphasize that the experimental group students outperformed their counterparts of the control group concerning their motivation level due to studying the proposed course. Consequently, the third hypothesis of the study is also verified.

\section{Testing the fourth hypothesis}

The fourth hypothesis addressed the difference between the mean scores of the experimental group's pre and post administration of the reading motivation scale. The following table shows these differences. 


\section{Rehab Hamadtoh Abul-Ghait Gohar}

Table 7.

Comparing the pre-post scores of the experimental group of the reading motivation scale

\begin{tabular}{cccccccc}
\hline $\begin{array}{c}\text { Motivation } \\
\text { scale }\end{array}$ & $\begin{array}{c}\text { Measure- } \\
\text { ment }\end{array}$ & $\boldsymbol{N}$ & Mean & SD & $\boldsymbol{t}$ & $\begin{array}{c}\text { D. } \boldsymbol{f} \\
(\boldsymbol{n}-1)\end{array}$ & Sig. (2-tailed) \\
\hline $\begin{array}{c}\text { Towards } \\
\text { reading }\end{array}$ & Pre & 50 & 53.9400 & .79308 & & 49 & $\begin{array}{c}\text { Significant at } \\
0.05\end{array}$ \\
\cline { 2 - 7 }
\end{tabular}

Based on table (7), the estimated $t$-value is significant at 0.05 level. This illustrates that there is a statistically significant difference between the experimental group students' mean scores on the pre-postadministration of the teaching analytic motivation scale in favor of the post-administration due to the proposed infographics-based ESP course. Therefore, the fourth hypothesis is accepted.

\section{Testing the fifth hypothesis}

The fifth hypothesis is "The effectiveness of the proposed infographics-based ESP course in enhancing students' critical reading skills is more than (1.2) when measured by Black's modified gain percentage and more than (0.6) when measured by Mac Gogian's effectiveness percentage". Black's modified gain percentage and Mac Gogian's effectiveness percentage were estimated as presented in the following table.

Table 8.

Pre-post critical reading skills test's mean scores, Black's modified gain percentage and Mac Gogian's effectiveness percentage

\begin{tabular}{ccccc}
\hline $\begin{array}{c}\text { Maximum } \\
\text { score }\end{array}$ & $\begin{array}{c}\text { Mean } \\
\text { scores of } \\
\text { pre-test }\end{array}$ & $\begin{array}{c}\text { Mean } \\
\text { scores of } \\
\text { post-test }\end{array}$ & $\begin{array}{c}\text { Black's modified } \\
\text { gain percentage }\end{array}$ & $\begin{array}{c}\text { Mac Gogian's } \\
\text { effectiveness } \\
\text { percentage }\end{array}$ \\
\hline 28 & 6.9 & 25.1 & 1.5 & 0.86 \\
\hline
\end{tabular}

As illustrated in the previous table, Black's modified gain percentage is 1.5 and Mac Gogian's effectiveness percentage is 0.86 which is more than 0.6. This indicates that the ESP course is effective in developing graduate nursing major students' critical reading; consequently, the fifth hypothesis is accepted and verified.

\section{Testing the sixth hypothesis}

The six hypothesis is "The effectiveness of the proposed infographicsbased ESP course in enhancing students' reading motivation is more than (1.2) when measured by Black's modified gain percentage and more than 
A Proposed Infographics-Based ESP Course for Enhancing Graduate Nursing Major Students' critical Reading Skills and Motivation

(0.6) when measured by Mac Gogian's effectiveness percentage". The following table presents the results of testing this hypothesis.

Table 9.

Pre-post motivation scale's mean scores, Black's modified gain percentage and Mac Gogian's effectiveness percentage

\begin{tabular}{ccccc}
\hline $\begin{array}{c}\text { Maximum } \\
\text { score }\end{array}$ & $\begin{array}{c}\text { Mean } \\
\text { scores of } \\
\text { pre-scale }\end{array}$ & $\begin{array}{c}\text { Mean } \\
\text { scores of } \\
\text { post-scale }\end{array}$ & $\begin{array}{c}\text { Black's modified } \\
\text { gain percentage }\end{array}$ & $\begin{array}{c}\text { Mac Gogian's } \\
\text { effectiveness } \\
\text { percentage }\end{array}$ \\
\hline 150 & 87.7 & 127.4 & 1 & 0.64 \\
\hline
\end{tabular}

As illustrated in the previous table, Black's modified gain percentage is (1) which is very close to the target value (1.2) and Mac Gogian's effectiveness percentage is (0.64) which is more than 0.6. This indicates that the ESP course is effective in developing graduate nursing major students' reading motivation; therefore, the six hypothesis is considered acceptable.

\section{Discussion}

The current research aimed at investigating the impact of a proposed infographics-based ESP course on enhancing graduate nursing major students' critical reading skills and motivation towards reading. To reach this aim, the target graduate nursing students' needs were analyzed and their need to improve their reading skills was emphasized. Enhancing students' motivation towards reading was also targeted due to the strong mutual influence between students' ability to read and motivation. In this concern, Guthrie \& Wigfield (2000), Grabe \& Stoller (2002), Andreassen \& Bråten (2010) and Ahmadi (2017) indicated that motivation is one of the important elements that greatly affect reading and understanding texts.

The infographics-based ESP course was designed following an integrated approach for ESP course design recommended by Nurpahmi (2016), as these major steps were adapted and used: needs analysis, syllabus design, implementation and evaluation. The sessions of the course followed the pre-while-post reading phases for addressing the target critical reading skills. The genuine/authentic reading texts and infographics used in the course were effective in improving the target critical reading skills. Such authentic reading materials increased students' motivation and exposed them to real language and culture as well as to the different genres of the professional community. The same 


\section{Rehab Hamadtoh Abul-Ghait Gohar}

effect was also emphasized by Marzban and Davaji (2015) who concluded that using authentic texts in classrooms has a positive impact on students' reading comprehension and motivation.

The various reading tasks, materials and tools employed in the ESP course (authentic infographics, Facebook, Piktochart and Padlet) helped students to interact, design and publish their infographics; in addition, practice discussion, collaboration and critical thinking skills. The use of infographics supported presenting complex information quickly and clearly through simplifying it in a visually engaging way in order to attract and inform the target participants. As shown in the previously illustrated statistical results, the proposed ESP course with infographics positively affected the students' target critical reading skills and their motivation towards reading.

These findings support the earlier studies carried out on investigating the significance of using infographics-based courses. For example, Noh (2014), Dyjur and Li (2015), Alrwele (2017) and Fadzil (2018) reached that using infographics positively facilitated students' learning, improved their visual literacy skills, enhanced their creativity and productivity and supported their critical thinking skills. Moreover, results of the current research are also congruent with Dahmash, Al-Hamid and Alrajhi (2017) and Manowong (2017) who examined the use of infographics with improving various language skills and they reached that engaging students in infographics-based activities led to their active participation in reading and developing positive motivation towards reading with infographics. In addition, their results concluded that infographics enhanced graduate students' collaborative and communication skills and critical reading. The same result was emphasized by the current research as the infographics assignments promoted students' critical thinking skills, enhanced visual literacy, and required the learner to demonstrate innovation and self-direction.

In this research, the graduate nursing students were enthusiastic about the opportunity to read about scientific and nursing issues displayed in a visual form. They described in their reflective logs that their participation in such an innovative assignment had created a meaningful experience for them. They mentioned also that the use of pictures, charts, photographs to build a context of the text in question is so beneficial, attractive and thus motivating. As well, they referred to online tools used simply in the course as stimulating and interactive sources which promoted a more active approach towards reading. Furthermore, they provided positive feedback regarding adherence to the learning objectives, visual appeal of 
A Proposed Infographics-Based ESP Course for Enhancing Graduate Nursing Major Students' critical Reading Skills and Motivation

the infographic, and its use for learning. They reported that learning objectives were met, and they felt highly engaged in the learning process.

\section{Conclusion}

The above findings make clear that the proposed treatment was effective in enhancing graduate nursing students' critical reading skills and motivation. The proposed infographics-based ESP course directly addressed students' critical reading needs through employing different materials and tools such as authentic infographics and reading texts, Facebook, Picktochart and Padlet. The experimental group who learned through such innovative means outperformed the control group who studied through the regular English. This, in turn, supported the effectiveness of the proposed infographics-based ESP course in enhancing nursing students' critical reading skills and motivation towards reading. Further research on experimenting the use of infographics with other language skills is highly recommended. Moreover, other recommendations of the research include that planners of the preuniversity stages should enrich the curricula with reading infographics. Besides, textbook writers should consider the use of infographics for supporting readers' comprehension and enhancing their reading motivation. 


\section{References}

Ahmadi, M. R. (2017). The impact of motivation on reading comprehension. International Journal of Research in English Education. Available

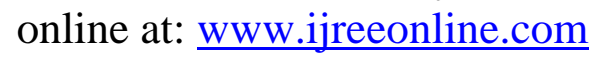

Akın, F., Koray, O., and Tavukçu, K. (2015). How effective is critical reading in the understanding of scientific texts? Procedia - Social and Behavioral Sciences 174, 2444 - 2451. Available online at www.sciencedirect.com

Abdel-Ghany, S. Y. and Abdel-Latif, M. M. (2012). English language preparation of tourism and hospitality undergraduates in Egypt: Does it meet their future workplace requirements? Journal of Hospitality, Leisure, Sport \& Tourism Education, 11 (2), 93-100.

Albeckay, E. M. (2014). Developing reading skills through critical reading programme amongst undergraduate EFL students in Libya. Procedia - Social and Behavioral Sciences 123, 175 - 181. Available online at www.sciencedirect.com

Ali, W. E. (2015). Motivations and attitudes of undergraduate students toward ESP classes in an Egyptian university. Digital Archive and Research Repository, the American University in Cairo. Available online at: http://dar.aucegypt.edu/handle/10526/3961

Alrwele, N. S. (2017). Effects of infographics on student achievement and students' perceptions of the impacts of infographics. Journal of Education and Human Development, 6 (3), 104-117.

Andreassen, R., \& Bråten, I. (2010). Examining the prediction of reading comprehension on different multiple-choice tests. Journal of Research in Reading, 33(3), 263-283.

Belyaeva, A. (2015). English for specific purposes: Characteristic features and curriculum planning steps. Sustainable Multilingualism, Vol. 7, 73-91. Available online at: http://uki.vdu.lt/sm/index.php/sm/article/view/103

Bouklikha, W. G. (2016). Practice of the reading skill in an ESP context using web-retrieved materials: The case of engineering students at the University of Tlemcen. Ph. D. thesis, Faculty of Letters and Languages, Tlemcen University.

Bracaj, M. (2014). Teaching English for specific purposes and teacher training. European Scientific Journal, 10 (2), 40-49.

Bradshaw, M. and Porter, S. (2017). Infographics: a new tool for the nursing classroom. Nurse Educator, 42 (2): 57-59.

Chetsadanuwat, K. (2018). Needs of English skills of Thai nurses working in international hospitals accredited by JCI in Bangkok area. 
A Proposed Infographics-Based ESP Course for Enhancing Graduate Nursing Major Students' critical Reading Skills and Motivation

Language Education and Acquisition Research Network Journal, 11 (1), 26- 46.

Dahmash, A., Al-Hamid, A. and Alrajhi, M. (2017). Using infographics in the teaching of linguistics. Arab World English Journal (AWEJ), 8 (4), 430- 443.

Davis, M. and Quinn, D. (2018). Visualizing text: the new literacy of infographics. Available online at:

https://www.academia.edu/5615673/Visualizing_Text_The_New_ Literacy_of_Infographics

Duarte, N. (2008). Slideology: The art and science of creating great presentations. Sebastopol, CA: O'Reilly.

Dunlap, J. C., \& Lowenthal, P. R. (2016). Getting graphic about infographics:

Design lessons learned from popular infographics. Journal of Visual Literacy, 35 (1), 42-59.

Dudley, E. and St Johns (1998). Developments in ESP a Multi-Disciplinary Approach. Cambridge: Cambridge University Press.

Dyjur, P. and Li, L. (2015). Learning 21st century skills by engaging in an infographics assignment. In Babb, P. et al, (Eds.). Proceedings of the IDEAS: Designing Responsive Pedagogy, pp. 62-71. Werklund School of the Education, University of Calgary. Available online at: https://prism.ucalgary.ca/bitstream/handle/1880/50860/7\%20Lear ning $\% 2021 \mathrm{st} \% 20-$ \%20Dyjur\%20\%26\%20Li.pdf?sequence $=1 \&$ isAllowed $=\mathrm{y}$

Gee, J. P. (2007). What Video Games Have to Teach Us About Learning and Literacy (2nd ed.). New York: Palgrave Macmillan

Grabe, W., \& Stoller, F. L. (2002). Teaching and Researching Reading. New York: Pearson Education.

Guthrie, J.T., \& Wigfield, A. (2000). Engagement and motivation in reading. In Kamil, M.L., Mosenthal, P.B., Pearson, P.D., \& Barr, R. (Eds.), Handbook of reading research: Volume III. New York: Erlbaum.

Hutchison, T. \& Waters, A. (1987). English for Specific Purposes: a learnercentered approach. London: Cambridge University Press.

Hyland K. (2007) English for Specific Purposes. In Cummins J., Davison C. (eds) International Handbook of English Language Teaching. Springer International Handbooks of Education, vol 15. Springer, Boston, MA. 


\section{Rehab Hamadtoh Abul-Ghait Gohar}

Kirkgoz, Y. (2007). Designing a Task-Based ESP Syllabus. In Gálová, D. (Ed). Languages for Specific Purposes: Searching for Common Solutions. Newcastle: Cambridge Scholars Publishing.

Kress , G. ( 2003 ). Literacy in the new media age. London: Routledge.

Lamb, A. \& Jhonson, L. (2014). Infographics part 1: Invitations to inquiry. Teacher Librarian, 41 (4), 54-58.

Lamri, C. E. (2016). An introduction to English for specific purposes. Available online at:

https://faclettre.univtlemcen.dz/assets/uploads/DOCUMENTS/cours\%20en\%20ligne/ 4-An\%20Introduction\%20to\%20ESP\%20LAMRI.pdf

Larouz, M. \& Kerouad, S. (2016). Demystifying the disparity between ESP and EGP methodology. Arab World English Journal, December, 97105. Available online at:

http://www.academia.edu/30969497/Demystifying the Disparity between_ESP_and_EGP_Methodology

Manarin, K., Carey, M., Rathburn, M., \& Ryland, G. (2015). Critical reading in higher education: Academic goals and social engagement. Bloomington, IN: Indiana University Press.

Manowong, S. (2017). Incorporating online tools to promote English reading for EFL learners: an action research study. $P A S A A P A R I T A$ T Journal, 32, 98- 124.

Marenzi, I. and Kantz, D. (2013). ESP course design - a multi-literacies approach. In: Reshaping Learning: Transforming Education through the Fusion of Learning and Technology, Proceedings of the 13th IEEE International Conference on Advanced Learning Technologies (ICALT 2013). Beijing, China.

Marzban, A. and Davaji, S. (2015). The effect of authentic texts on motivation and reading comprehension of EFL students at intermediate level of proficiency. Theory and Practice in Language Study, 15 (1). Available online at: http://www.academypublication.com/ojs/index.php/tpls/article/vie w/tpls05018591/0

Mickelson, N. (2018). Cultivating critical reading: Using creative assignments to promote agency, persistence, and enjoyment. Transformative Dialogues: Teaching \& Learning Journal, 11 (1), 1-14.

Noh et al. (2014). The Use of infographics as a tool for facilitating learning. Available online at: https://www.researchgate.net/publication/284180153 The Use of _Infographics_as_a_Tool_for_Facilitating_Learning 
A Proposed Infographics-Based ESP Course for Enhancing Graduate Nursing Major Students' critical Reading Skills and Motivation

Nurpahmi, S. (2016). ESP course design: an integrated approach. Lentera Pendidikan. 19 (2), 172-181.

Parrish, P. (2009). Aesthetic principles for instructional design. Educational Technology Research \& Development, 57, 511-528.

Popa, D. E. (2013). Medical discourse and ESP courses for Romanian nursing undergraduates. 2nd World Conference on Educational Technology Researches - WCETR2012. Procedia - Social and Behavioral Sciences, 83 (2013) 17 - 24. Available online at www.sciencedirect.com

Popescu, A. (2010). A General view on the relationship between ESP and EGP. Professional Communication and Translation Studies, $3,1-2,49-52$.

Retelsdorf, J., Köller, O., and Möller, J. (2011). On the effects of motivation on reading performance growth in secondary school. Learning and Instruction, 21(4), 550-559.

Salazar, E. U. (2017). Designing and implementing an ESP course: Revisiting an experience. Revista Pensamiento Actual, 17 (28), 197-207.

Schiefele, U., Schaffner, E., Möller, J., and Wigfield, A. (2012). Dimensions of reading motivation and their relation to reading behavior and competence. Reading Research Quarterly, 47(4), 427-463.

Sukerti, G., Yuliantini, N. and Susana, K. (2018). Students" Voices and Choices in Project-Based Learning: Driving Engagement through Essay Writing and Infographic Design. 1st International Conference on Social Sciences. Advances in Social Science, Education and Humanities Research, volume 226, 607-618.

Thuy, T. (2017). Critical reading: A guidebook for postgraduate students. Vietnam: Hue University Publishing House.

Vaezi, S. (2001). Metacognitive reading strategies across language and techniques (Unpublished doctoral dissertation). Allameh Tabataba'i University, Tehran, Iran.

Vanicheva, T., Kah, M. and Ponidelkoa, L. (2015). Critical thinking within the current framework of ESP curriculum in technical universities of Russia. Social and Behavioral Sciences, 199, 657 - 665. Available online

https://www.sciencedirect.com/science/article/pii/S187704281504 6145?via\%3Dihub

Yildirim, S. (2017). Approaches of designers in the developed educational purposes of infographics' design processes. European Journal of Education Studies, 3 (1), 249-284. 